\title{
Cytosine Arabinoside Transport and Metabolism in Acute Leukemias and T Cell Lymphoblastic Lymphoma
}

J. S. Wiley, J. Taupin, G. P. Jamieson, M. Snook, W. H. Sawyer, and L. R. Finch

Department of Haematology, Austin Hospital, Studley Road, Heidelberg, 3084 Australia; Russell Grimwade School of Biochemistry, University of Melbourne, Parkville, 3052 Australia

\begin{abstract}
Cytosine arabinoside (araC) has proven efficacy in acute myeloid leukemia (AML), but its place in the treatment of acute lymphoblastic leukemia (ALL) and T lymphoblastic lymphoma is uncertain. The therapeutic potential of araC has been assessed in patients with AML, ALL, and Tymphoblastic lymphoma by measuring the conversion of araC to its active metabolite, the 5'-triphosphate of araC (araCTP), in purified blasts from patients as well as in normal polymorphs and lymphocytes. In all leukemias, araCTP was the major intracellular metabolite of araC. The highest araCTP formation was in blasts from $\mathbf{T}$ lymphoblastic lymphoma, which formed threefold more nucleotide than myeloblasts, and in turn myeloblasts formed twofold more araCTP than lymphoblasts from ALL. The mean araCTP formation in myeloblasts was sixfold greater than polymorphs, but in contrast, lymphoblasts and lymphocytes formed low and similar amounts of this nucleotide. Reasons for the sixfold range in araCTP accumulation in the various leukemic blasts were studied. The mean size of myeloblasts was 35-70\% larger than lymphoblasts when compared on the basis of protein or intracellular water content, but $T$ lymphoblastic lymphoma blasts and lymphoblasts were the same size. Activities of deoxycytidine kinase, deoxycytidylate deaminase, and pyrimidine nucleoside monophosphate kinase were not different between any of the leukemic cell types. The number of nucleoside transport sites on blasts was estimated by measuring the equilibrium binding of $\left[{ }^{3} \mathrm{H}\right]$ nitrobenzylthioinosine (NBMPR), which binds with high affinity to the transporter. Scatchard analysis yielded mean values of 27,500 sites/cell for $T$ lymphoblastic lymphoma blasts, 10,000 sites/ cell for myeloblasts, and 2,300 sites/cell for lymphoblasts. Our previous work has shown that araC influx correlates with the maximum number of ${ }^{3} \mathrm{H}-\mathrm{NBMPR}$ binding sites in leukemic and normal white cells. A strong correlation was observed between the number of nucleoside transport sites per leukemic blast cell and the accumulation of intracellular araCTP from extracellular araC at $1 \mu \mathrm{M}$. Membrane transport of araC at the low concentrations $(\sim 1 \mu M)$, which are achieved therapeutically, is a major rate-limiting step in its conversion to araCTP by leukemic blast cells. Myeloblasts form more araCTP than lymphoblasts because of both higher nucleoside transport capacity and larger cell size. The highest nucleoside transport capacity and largest conversion of araC to araCTP is in
\end{abstract}

This paper has appeared in abstract form in 1982 (Blood. 60:159a).

Received for publication 9 November 1983 and in revised form 22 October 1984

J. Clin. Invest.

(c) The American Society for Clinical Investigation, Inc.

0021-9738/85/02/0632/11 $\$ 1.00$

Volume 75, February 1985, 632-642
T lymphoblastic lymphoma, which suggests that araC may be effective in the treatment of this disease.

\section{Introduction}

Although cytosine arabinoside ( $\mathrm{araC})^{1}$ is generally considered to be the major drug in the treatment of acute myeloblastic leukemia (AML), its place in the therapy of acute lymphoblastic leukemia (ALL) is still uncertain. Chemotherapy with araC as a single agent in childhood ALL gives variable results, since in three studies complete remission rates of between 3 and $32 \%$ have been reported (1-3). Two more recent trials suggest that araC given in combination with another agent is effective in the treatment of relapsed or refractory $\operatorname{ALL}(4,5)$, but a third study showed that addition of araC to other drugs did not improve either remission rate or disease-free duration of adult ALL beyond that obtained with standard agents (6). This variable response to araC may relate to the immunological heterogeneity of ALL.

A prerequisite for cell kill by araC is transport of this nucleoside into the cell and its conversion to the 5'-triphosphate of $\operatorname{araC}(\operatorname{araCTP})$ by a pathway shown in Fig. 1. AraCTP is generally considered to be the active form of the drug, since it both inhibits DNA polymerase (7) and leads to araC incorporation into DNA (8). The loss of clonogenic survival of human leukemic cells correlates with the extent of (araC)DNA formation, which in turn is predicted by the product of araCTP level and time (9). It is well documented that myeloblasts can convert araC to its triphosphate (10-12). In contrast, there is little information on araC metabolism for fresh lymphoblasts and the reasons for the relative resistance of ALL to this drug. Studies in AML, however, show that $10-20 \%$ of these patients have poor accumulation of araCTP from araC, which correlates with failure to respond to this drug $(10,13)$. The basis of this therapeutic resistance to ara $\dot{C}$ has been shown to reside in low membrane transport (step 1 of Fig. 1) of the drug (14). Low membrane transport of araC has also been demonstrated in lymphoblasts, and this may be one factor in the relative insensitivity of ALL to this drug $(14,15)$. Reduced activity of deoxycytidine kinase (step 2 of Fig. 1) has also been suggested as a possible mechanism of resistance to $\mathrm{araC}$, but levels of

1. Abbreviations used in this paper: ALL, acute lymphoblastic leukemia; AML, acute myeloblastic leukemia; AMML, acute myelomonocytic leukemia; araC, 1- $\beta$-D-arabinofuranosylcytosine; araU, 1- $\beta$-D-arabinofuranosyluracil; $\mathrm{CdR}$, deoxycytidine; araCDP, $5^{\prime}$-diphosphate of araC; araUDP, 5'-diphosphate of araU; $K_{d}$, dissociation constant; DTT, 1,4dithiothreitol; araCMP, 5'-monophosphate of araC; araUMP, 5'-monophosphate of araU; dCMP, $5^{\prime}$ monophosphate of deoxycytidine; dUMP, 5 ' monophosphate of deoxyuridine; NBMPR, nitrobenzylthioinosine, or 6-([4-nitrobenzyl]thio)9- $\beta$-D-ribofuranosyl purine; PEI-cellulose, polyethyleneimine-cellulose; araCTP, 5 '-triphosphate of araC; araUTP, 5'-triphosphate of araU; dCTP, 5 ' triphosphate of deoxycytidine. 


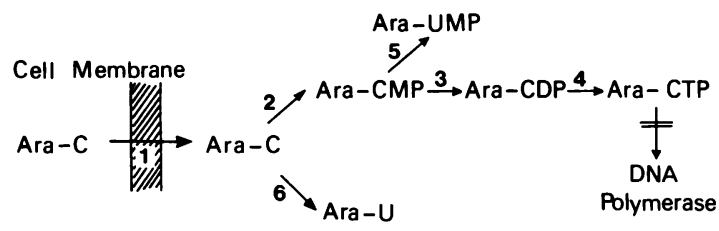

Figure 1. Metabolic pathway leading from araC to its active metabolite araCTP. Blast cells from various leukemias were assayed for maximal density of nucleoside transport sites (step 1) and maximal activities of deoxycytidine kinase (step 2), pyrimidine nucleoside monophosphate kinase (step 3) and deoxycytidylate deaminase (step 5). Nucleoside diphosphate kinase (step 4) was not assayed, while the deamination of araC by cytidine deaminase (step 6) was assessed by measuring araU in the medium. AraCTP inhibits DNA polymerase and also leads to some incorporation of araC into DNA.

this enzyme in ALL have not been reported (16). In the present study, the nucleoside transport site density of blast cells as well as their content of deoxycytidine kinase, pyrimidine nucleoside monophosphate kinase, and deoxycytidylate deaminase have been assayed in a variety of different leukemias. The formation of araCTP from araC has also been measured and found to correlate closely with the nucleoside transport site density of blast cells. An extremely high nucleoside transport site density and correspondingly large araCTP formation have been found in $\mathrm{T}$ cell lymphoblastic lymphoma, which suggests that nucleoside antimetabolites may be effective in the treatment of this variant of lymphoblastic leukemia.

\section{Methods}

Materials. Imidazole-buffered saline $(145 \mathrm{mM} \mathrm{NaCl}, 5 \mathrm{mM} \mathrm{KCl}, 5.0$ $\mathrm{mM}$ imidazole- $\mathrm{Cl}, 1.0 \mathrm{mM} \mathrm{MgCl}$, and $5.0 \mathrm{mM}$ glucose, $\mathrm{pH}$ 7.4) was ultrafiltered through millipore Millex $0.22-\mu \mathrm{m}$ filter units (Millipore Corp., Bedford, MA) before use. All washing and incubation media contained deoxyribonuclease $(10 \mu \mathrm{g} / \mathrm{ml}$, Sigma Chemical Co., St. Louis, MO) to reduce the tendency of leukocytes to clump. Carbonyl iron (grade SF) of nominal particle diameter $(3 \mu \mathrm{m})$ was obtained from GAF Corp., New York; Dextran T500 and Ficoll-Paque ( $d$ $=1.077 \mathrm{~g} / \mathrm{ml}$ ) were obtained from Pharmacia Fine Chemicals (Uppsala, Sweden). Di- $n$-butyl-phthalate (British Drug Houses, Poole, England) and di-n-octyl-phthalate (Ajax Chemicals Ltd., Sydney, Australia) of $d$ $=1.044$ and $0.986 \mathrm{~g} / \mathrm{ml}$, respectively, were blended $4: 1$ (vol/vol), and yielded an oil mixture of $d=1.032 \mathrm{~g} / \mathrm{ml}$. Dow Corning DC702 and DC200 oils (Dow Corning Corp., Midland, MI) of $d=1.07$ and 0.873 $\mathrm{g} / \mathrm{ml}$ and viscosities 45 and 2 centistokes, respectively, were blended 4:1 (vol/vol), and yielded an oil mixture of $d=1.031 \mathrm{~g} / \mathrm{ml}$ ("silicone oil mix"). Nitrobenzylthioinosine (NBMPR) was a gift from Professor A. R. P. Paterson, University of Alberta, Edmonton, Canada. On the day of each experiment, NBMPR was stirred vigorously with imidazolebuffered saline for $4 \mathrm{~h}$ at $18-20^{\circ} \mathrm{C}$ to yield a saturated solution of $\sim 20 \mu \mathrm{M}$. G- ${ }^{3} \mathrm{H}-\mathrm{NBMPR} 5{ }^{3} \mathrm{H}-5^{\prime}$ monophosphate of deoxycytidine (dCMP) and 5,6- ${ }^{3} \mathrm{H}-5^{\prime}$-monophosphate of araC (araCMP) were from Moravek Biochemicals Ltd., Brea, CA. $5-{ }^{3} \mathrm{H}$-araC, $5-{ }^{3} \mathrm{H}$-deoxycytidine (CdR), and $\mathrm{U}-{ }^{14} \mathrm{C}$-polyethylene glycol 4000 in sterile $3 \%$ aqueous ethanol were from the Radiochemical Centre, Amersham, England. Solutions of $5.0 \mathrm{mM}$ cytosine arabinoside and $5.0 \mathrm{mM}$ deoxycytidine (Upjohn Co., Kalamazoo, MI) as well as dCMP (4-32 mM) and araCMP (2-16 $\mathrm{mM})$ in isotonic saline were mixed with varying volumes of the appropriate tritiated stock for the kinase assays; the exact concentration of the final solution was confirmed spectrophotometrically at $\mathrm{pH} 1$ using a molar extinction coefficient of $1.32 \times 10^{4}$ at $280 \mathrm{~nm}$. For araCTP experiments, $5{ }^{3} \mathrm{H}$-araC was diluted with isotonic saline ( $\mathrm{pH} 7$ ) to give a stock solution of $23.3 \mu \mathrm{M}$, and was confirmed spectrophotometrically using a molar extinction coefficient of $0.90 \times 10^{4}$ at $271 \mathrm{~nm}$. AraCTP and araCMP were from CalbiochemBehring Corp. (La Jolla, CA), dCMP from Sigma Chemical Co. (St. Louis, MO), tetrahydrouridine was from Cordova Chemical Co. (Sacramento, CA), and phosphoenol pyruvate, pyruvate kinase, and myokinase were from Boehringer Mannheim GmbH, Mannheim, Federal Republic of Germany. Biorad reagent was from Bio-rad Laboratories (Richmond, CA) and DEAE-cellulose (DE-81) paper from Whatman (England). Polyethylene-imine thin layer plates were prepared as described previously (17) using Avicel pH105 in place of Avicel SF. Scintillant fluid consisted of 2 vol toluene, 1 vol Triton X-100, plus $4 \mathrm{~g}$ 2,5-diphenyloxazole (Packard Instruments Co., Downers Grove, IL) per liter, used in a ratio of $1 \mathrm{ml}$ aqueous phase to $10 \mathrm{ml}$ scintillant (18).

Patient data. Patients with AML $(n=4)$, acute myelomonocytic leukemia (AMML) $(n=5)$, acute monocytic leukemia $(n=1)$, acute promyelocytic leukemia $(n=1)$, and non T-ALL $(n=7)$ had peripheral leukocyte counts of $16,800-375,000 / \mu \mathrm{l}$ (38-99\% blasts) and were diagnosed from morphology of blood and bone marrow specimens. Patients ranged in age from 4 to $72 \mathrm{yr}$. All samples were collected with informed consent from patients before initial chemotherapy. Two patients (one AML, one ALL) had relapsed, but had received no treatment for 3 wk before study. Additional patients (AML, AMML [ $n=14]$, and non-T ALL $[n=8]$ ) were included only for the dCMP deaminase assay. Acute lymphoblastic leukemia was diagnosed when blasts of lymphoid morphology gave two of the following: block positivity with the periodic acid-Schiff stain, a common-ALL antigen reaction, or an elevated terminal deoxynucleotidyl-transferase activity. All seven patients with ALL had blasts which failed to rosette with sheep erythrocytes and possessed no surface immunoglobulin. Other leukemias were diagnosed according to the French-American-British classification (19). Because AML and AMML are derived from a common stem cell, these two leukemias were analyzed in the one category. B lymphoblasts were obtained from a 72-yr-old man with rapidly progressive diffuse, poorly differentiated lymphocytic lymphoma. His disease was unresponsive to combination chemotherapy with cyclophosphamide, vincristine, and prednisolone, followed by cyclophosphamide, adriamycin, vincristine, and prednisolone, and within 5 mo of diagnosis he entered a terminal leukemic phase with rapidly advancing lymphadenopathy and hepatosplenomegaly. The peripheral blood contained $175,000 / \mu$ l white cells, of which $94 \%$ were large, immature lymphoid cells possessing strongly reacting surface immunoglobulin. The three patients with $\mathrm{T}$ cell lymphoblastic lymphoma, who were aged 6,15 , and 29 , were diagnosed from histology of a lymph node biopsy (20). All had a mediastinal mass as well as hepatosplenomegaly and peripheral lymphadenopathy. The two youngest were leukemic at presentation with peripheral leucocyte counts of $610,000 / \mu \mathrm{l}$ and $100,000 / \mu \mathrm{l}(92.5$ and $84 \%$ blasts typed as T cells). The third patient was not leukemic at presentation and was treated with cyclophosphamide, adriamycin, vincristine, and prednisolone combination chemotherapy. Within $3 \mathrm{yr}$, he relapsed both in the central nervous system and with a leukemic peripheral blood picture. On the day of study his white cell count was $99,000 / \mu \mathrm{l}$ (63\% blasts all typed as $\mathrm{T}$ cells).

White cell and blast isolation. Venous blood from healthy subjects (120-180 ml) was defibrinated and lymphocytes and blasts separated by density centrifugation on a Ficoll-Paque gradient as previously described (14). Polymorphonuclear leukocytes were prepared from defibrinated venous blood $(60-180 \mathrm{ml})$ from normal donors by initial sedimentation in $0.4 \%$ Dextran T500, after which the supernate (containing mainly leukocytes) was centrifuged over a Ficoll-Paque density gradient. The cell pellet of polymorphs was resuspended in 2 $\mathrm{ml}$ of imidazole-buffered saline and residual red cells lysed by hypotonic shock (9:1 water/cell suspension) at $4^{\circ} \mathrm{C}$ for $30 \mathrm{~s}$, after which isotonicity was restored and cells again washed thrice.

Measurement of ${ }^{3} \mathrm{H}-\mathrm{NBMPR}$ binding. Cell suspensions (each 1.2 $\mathrm{ml}$ ) were preincubated in stoppered plastic tubes at $37^{\circ} \mathrm{C}$ for $5 \mathrm{~min}$, ${ }^{3} \mathrm{H}-\mathrm{NBMPR}(0.1-6.0 \mathrm{nM})$ added, and tubes gently mixed. Aliquots of $1.0 \mathrm{ml}$ were taken after $6 \mathrm{~min}$ incubation at $37^{\circ} \mathrm{C}$, layered over 0.3 
$\mathrm{ml}$ silicone oil mix and cells separated by centrifuging at $8,000 \mathrm{~g}$ for 4 min. The supernatant above the oil was sampled and counted to determine the concentration of free NBMPR. The remainder of the supernatant was aspirated, the walls of the microfuge tubes washed thrice with $\mathrm{H}_{2} \mathrm{O}$, and most of the oil removed with the final washing. Cell pellets were solubilized in $0.5 \mathrm{ml} 0.5 \mathrm{~N} \mathrm{NaOH}$, washed over into vials with $0.4 \mathrm{ml} 0.5 \mathrm{~N} \mathrm{NaOH}$, scintillation fluid added, and the vial contents were acidified and counted. The specific activity of ${ }^{3} \mathrm{H}$ NBMPR was also measured to allow the calculation of ${ }^{3} \mathrm{H}-\mathrm{NBMPR}$ binding in picomoles per $10^{7}$ cells. The nonspecific binding of ${ }^{3} \mathrm{H}$ NBMPR was measured in parallel incubations of cells to which unlabeled NBMPR $(3 \mu \mathrm{M})$ was added before the ${ }^{3} \mathrm{H}-\mathrm{NBMPR}$ addition. Specific binding was taken as the difference between the isotope binding to cells incubated with ${ }^{3} \mathrm{H}-\mathrm{NBMPR}$ and those incubated with unlabeled NBMPR plus ${ }^{3} \mathrm{H}-\mathrm{NBMPR}$. The correction for ${ }^{3} \mathrm{H}-\mathrm{NBMPR}$ trapped in the extracellular space of the cell pellet, measured in each experiment as the ${ }^{14} \mathrm{C}$-polyethylene glycol space, was always $<5 \%$ of the total pellet counts.

Metabolites of araC. Aliquots of the cell suspension $(1.2 \mathrm{ml})$ were preincubated for $5 \mathrm{~min}$ at $37^{\circ} \mathrm{C}$ and ${ }^{3} \mathrm{H}$-araC $(9.36 \mathrm{Ci} / \mathrm{mmol})$ was added to give a final concentration of $1 \mu \mathrm{M}$ and the suspension gently agitated at $37^{\circ} \mathrm{C}$. Aliquots of $1.0 \mathrm{ml}$ were removed between $15 \mathrm{~min}$ to $2 \mathrm{~h}$ incubation, layered over $0.3 \mathrm{ml}$ phthalate oil mix, beneath which was $100 \mu \mathrm{l}$ of $12 \%$ perchloric acid in a microfuge tube. Tubes were immediately centrifuged for $4 \mathrm{~min}$ at $8,000 \mathrm{~g}$, which separated cells from medium and also deproteinized blasts. The supernatant was aspirated, the walls of the microfuge tubes washed thrice with $\mathrm{H}_{2} \mathrm{O}$, and most of the oil removed with the final washing. The perchloric acid layer was vortexed, centrifuged $1 \mathrm{~min}$, and the supernatant removed and kept on ice. Phenol red indicator $(5 \mu \mathrm{l})$ was added and the extract neutralized with $5 \mathrm{M} \mathrm{K}_{2} \mathrm{CO}_{3}(\sim 7 \mu \mathrm{l})$. The precipitate was removed by centrifugation ( $100 \mathrm{~g}$ for $5 \mathrm{~min}$ ) and the supernatant kept on ice. Samples $(5 \mu \mathrm{l})$ of supernatant were spotted on a PEI cellulose thin layer plate followed by $5 \mu \mathrm{l}$ of cold marker solution containing 1 $\mathrm{mM}$ araCMP, $1 \mathrm{mM} 5^{\prime}$-diphosphate of araC (araCDP), and $1 \mathrm{mM}$ araCTP. Nucleotides were separated by ascending chromatography in $0.5 \mathrm{M}\left(\mathrm{NH}_{4}\right)_{2} \mathrm{SO}_{4}$, which gave $R_{\mathrm{f}}$ values of $0.31,0.52$, and 0.69 for araCTP, araCDP, and araCMP, respectively. The 5 -monophosphate of araU (araUMP) co-migrated with araCMP and these were always measured together. Material at the solvent front includes nucleosides and araCDP choline (21). The 5'-triphosphate of araU (araUTP) marker was not available, but it might be expected to chromatograph like its natural isomer uridine-5'-triphosphate, which ran with an $R_{\mathrm{f}}$ of 0.43 . Less than $1 \%$ of the total acid-soluble radioactivity appeared as araUTP. The absorbing bands were visualized by UV light, cut out and placed into scintillation vials, and nucleosides eluted with $1.0 \mathrm{ml}$ $0.5 \mathrm{~N}$ of $\mathrm{NaOH}$ overnight. Scintillation fluid was added followed by $100 \mu 111 \mathrm{~N} \mathrm{HCl}$ to acidify and the vials were counted (18). Recovery of radioactivity applied to the PE1 plates was $99 \%$. AraC phosphate production was calculated from the activity in that spot and the known specific activity of ${ }^{3} \mathrm{H}$-araC. The coefficient of variation for duplicates was $2-8 \%$. Chromatography of the medium after incubation showed araC and 1- $\beta$-D-arabinofuranosyluracil (araU) to be the only ultravioletabsorbing compounds present, and these were quantitated by column chromatography. Samples of media were added to small columns (3 $\times 0.44 \mathrm{~cm}$ ) of Bio-rad AG50w- $\times 8$ (200-400) mesh, (Bio-rad Laboratories) and araU was eluted in $0.5 \mathrm{ml}$ of $0.01 \mathrm{~N} \mathrm{HCl}$ followed by 0.5 $\mathrm{ml}$ water. AraC was then eluted with $1.0 \mathrm{ml}$ of $4 \mathrm{M} \mathrm{NH}_{4} \mathrm{OH}$ and radioactivity in each eluate measured (10).

Deoxycytidine kinase activity (EC 2.7.1.74). Washed leukemic blast cells were centrifuged at $750 \mathrm{~g}$ for $5 \mathrm{~min}$, and the cell pellet resuspended in $0.05 \mathrm{M}$ Tris $\mathrm{HCl}, \mathrm{pH}$ 8.0. The cells were lysed by four cycles of freeze thawing in a dry ice acetone bath. Cell debris was removed by centrifugation at $8,000 \mathrm{~g}$ for $15 \mathrm{~min}$, and the supernatant analyzed for enzyme activity and determination of protein content. Enzyme activity was assayed as described by Coleman et al. (22) with $10 \mathrm{mM}$ ATP, 10 $\mathrm{mM} \mathrm{MgCl}$, $50 \mathrm{mM}$ Tris-HCl (pH 7.6), $15.0 \mathrm{mM} \mathrm{NaF},{ }^{3} \mathrm{H}-\mathrm{CdR}(1-$ $30 \mu \mathrm{M})$, or ${ }^{3} \mathrm{H}$-araC $(5-120 \mu \mathrm{M})$, and $20 \mu \mathrm{l}$ of cell-free supernate in a total reaction volume of $120 \mu \mathrm{l}$. In addition, $1 \mathrm{mM}$ tetrahydrouridine was included in the assay to prevent substrate consumption by cytidine deaminase. An ATP regenerating system consisting of $15 \mathrm{mM}$ phosphoenol pyruvate, $3.6 \mathrm{U}$ myokinase, and $1.4 \mathrm{U}$ pyruvate kinase was also included. The assay mixture was incubated for $30 \mathrm{~min}$ at $37^{\circ} \mathrm{C}$ and the reaction terminated by immersing the tubes in boiling water for $1 \mathrm{~min}$. A $50-\mu \mathrm{l}$ aliquot was spotted on a $2-\mathrm{cm} \times 2-\mathrm{cm}$ square of Whatman DE-81 paper (Whatman, England), which was then washed four times in ice-cold $1 \mathrm{mM}$ ammonium formate. The paper squares were further washed twice with $70 \%$ ethanol and dried overnight. The paper squares were dropped into vials containing $1 \mathrm{ml}$ of $0.1 \mathrm{M} \mathrm{HCl}$ plus $0.2 \mathrm{M} \mathrm{KCl}$, the nucleotide eluted with gentle shaking of the vial, and radioactivity measured as above. A blank assay consisting of all substituents except enzyme was always included and gave $<20 \mathrm{cpm}$. Reaction rates were linear to $45 \mathrm{~min}$ incubation and this rate was related in a linear manner to extract protein concentration. Protein concentrations were determined by the dye-binding procedure of Bradford (23) using bovine serum albumin as a standard. The enzyme activity was stable for $2 \mathrm{~d}$ when extracts were stored frozen at $-20^{\circ} \mathrm{C}$.

Pyrimidine nucleoside monophosphate kinase assay (EC 2.7.4.14). Washed leukemic cells were resuspended at $2-8 \times 10^{7}$ cells $/ \mathrm{ml}$ in 20 $\mathrm{mM}$ phosphate buffer, $\mathrm{pH} 7.5$, with $2 \mathrm{mM} \mathrm{MgCl}_{2}$ and $50 \mathrm{mM} \mathrm{1,4-}$ dithiothreitol (DTT). Some assays were performed immediately, but when storage at $-70^{\circ} \mathrm{C}$ was necessary, activity of the enzyme was restored by a $15-\mathrm{min}$ preincubation at $37^{\circ} \mathrm{C}$ with $50 \mathrm{mM}$ DTT (24). An enzyme extract was prepared by four rapid freeze-thaw cycles of cell suspension using liquid nitrogen. Cell debris was removed by centrifugation at $8,000 \mathrm{~g}$ for $15 \mathrm{~min}$ at $4^{\circ} \mathrm{C}$. $25 \mu \mathrm{l}$ of supernate was preincubated at $37^{\circ} \mathrm{C}$ for $15 \mathrm{~min}$ with $10 \mu \mathrm{l}$ of $0.5 \mathrm{M}$ Tris-HCl, $\mathrm{pH}$

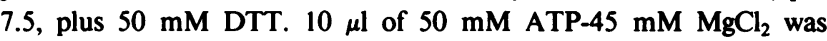
added, and followed immediately by $5 \mu \mathrm{l}$ of either ${ }^{3} \mathrm{H}-\mathrm{dCMP}$ (4-32 $\mathrm{mM} ; 3 \mathrm{mCi} / \mathrm{mmol})$ or ${ }^{3} \mathrm{H}$-araCMP $(2-16 \mathrm{mM} ; 6 \mathrm{mCi} / \mathrm{mmol})$ to initiate the reaction. The mixture was incubated at $37^{\circ} \mathrm{C}$ and at time intervals between 0 and 20 min samples $(5 \mu l)$ were removed and spotted onto polyethyleneimine-cellulose (PEI-cellulose) to terminate the reaction. Zero time samples showed $0.5 \%$ phosphorylation of substrate. Nucleotides were separated by ascending chromatography using $0.3 \mathrm{M} \mathrm{LiCl} / 1 \mathrm{M}$ acetic acid solvent (25) and labeled products measured as above. The nucleoside triphosphates remained at the origin and the diphosphates were well separated from the uridine monophosphate as shown by the $R_{\mathrm{f}}$ values: araCTP, 0 , araCDP, 0.16 , araUMP, 0.53 , araCMP, $0.81,5^{\prime}$ triphosphate of deoxycytidine (dCTP), $0,5^{\prime}$ diphosphate of deoxycytidine, $0.21,5^{\prime}$ monophosphate of deoxyuridine (dUMP), 0.56, and dCMP, 0.85. As the enzyme extract also contained the nucleoside diphosphate kinase, the sum of the nucleoside diphosphate and triphosphate was taken as the product of the reaction. Deamination of substrates to the corresponding uridine monophosphate was between 1 and 5\% and did not affect the linearity of the phosphorylation reaction with time. Reaction rates were related in a linear manner to extract protein concentration.

Deoxycytidylate deaminase assay (EC 3.5.4.12). Cell-free extracts were prepared by resuspending pellets in $0.02 \mathrm{M}$ phosphate buffer (pH 7.5) containing $2 \mathrm{mM}$ mercaptoethanol, $2 \mathrm{mM} \mathrm{MgCl}$, and $0.04 \mathrm{mM}$ dCTP. The cells were lysed by four cycles of freeze thawing in liquid nitrogen. Cell debris was pelleted in a Beckman airfuge for $15 \mathrm{~min}$ at $122,000 \mathrm{~g}$. Enzyme activity in the supernatant was assayed either immediately or after storage at $-80^{\circ} \mathrm{C}$ for up to $3 \mathrm{wk}$. Repeated assays of the same extract showed no loss of activity during 3 mo of cold storage and previous reports have demonstrated that this otherwise labile enzyme can be stabilized by dCTP and $\mathrm{MgCl}_{2}$ in the storage buffer (26). $30 \mu \mathrm{l}$ of cell-free extract was preincubated with $15 \mu \mathrm{l}$ of buffer and cofactors for $2 \mathrm{~min}$ at $37^{\circ} \mathrm{C}$. The reaction was started by the addition of $5 \mu \mathrm{l}$ of substrate to give final concentrations of 25-200 $\mu \mathrm{M}{ }^{14} \mathrm{C}$-dCMP ( $\left.2 \mathrm{mCi} / \mathrm{mmol}\right), 4.4 \mathrm{mM} \mathrm{MgCl} 2,3.2 \mathrm{mM}$ mercaptoethanol, $40 \mu \mathrm{M}$ dCTP, and $100 \mathrm{mM}$ Tris- $\mathrm{HCl}$ (pH 7.5).

Samples of $5 \mu \mathrm{l}$ were taken at $0,1,2,3$, and $4 \mathrm{~min}$ and immediately spotted on a 6-cm strip of PEI-cellulose on which a marker of $5 \mu \mathrm{l}$ of $2 \mathrm{mM}$ dUMP had already been spotted. The two nucleotides were separated by ascending chromatography with $1 \mathrm{M}$ formic acid. The strip was dried, examined under ultraviolet light, and the dUMP spot 
marked and cut out. After further drying in a stream of hot air the squares of PEI-cellulose were placed in liquid scintillation vials and 6 $\mathrm{ml}$ of 2,5-diphenyloxazole in toluene ( $4 \mathrm{~g}$ /liter) added for counting. Because protein was not measured in every cell extract, enzyme activity was expressed per $10^{6}$ cells. The reaction rate was linear to $5 \mathrm{~min}$ incubation, and this rate was related in a linear manner to the number of cells in the assay.

Intracellular water space. Cell suspensions were incubated for 5 min at $20^{\circ} \mathrm{C}$ with $\left[{ }^{3} \mathrm{H}\right] \mathrm{H}_{2} \mathrm{O}(5 \mu \mathrm{Ci} / \mathrm{ml})$ and aliquots layered over phthalate oil mix and centrifuged at $8,000 \mathrm{~g}$ for $4 \mathrm{~min}$. The trapped extracellular space was determined with ${ }^{14} \mathrm{C}$-polyethylene glycol in parallel tubes. Cell pellets were counted and intracellular water space calculated $(27,28)$.

Scatchard and kinetic analyses. The specific binding of ${ }^{3} \mathrm{H}-\mathrm{NBMPR}$ was analyzed by Scatchard plots and the maximum number of binding sites per cell was obtained by extrapolation of the regression line to the abscissa, while the dissociation constant $\left(K_{d}\right)$ was the reciprocal of the association constant given by the slope of the regression line. Examples of Scatchard plots for this system have been provided previously (14). Data were collected over a wide range of free ligand concentrations such that the semilogarithmic plots of the type suggested by Klotz (29) were sigmoidal, thus ensuring a more accurate estimate of the Scatchard abscissa intercept. Some data were also fitted using the nonlinear least squares procedures of Koeppe and Hamann (30) and of Duggleby (31).

The kinetics of deoxycytidine kinase, deoxycytidylate deaminase, and pyrimidine nucleoside monophosphate kinase were all well defined by a Michaelis-Menten treatment. The kinetic data were analyzed by means of plots of $S / V$ against $S$, to which linear regression lines were fitted as well as a nonlinear regression analysis of the raw data (31). Concordance was observed between estimates of the kinetic parameters from the two methods that were used to calculate the $K_{\mathrm{m}}$ and $V_{\max }$.

Statistics. Mean values \pm 1 SD are shown unless otherwise stated, and differences between means analyzed by a $t$ test.

\section{Results}

Ara-CTP formation from araC. Cell suspensions were incubated with $1 \mu \mathrm{M}{ }^{3} \mathrm{H}$-araC at $37^{\circ} \mathrm{C}$ for $15-120 \mathrm{~min}$ and the formation of araCTP measured. AraCTP production in all leukemias was approximately linear with time to $45 \mathrm{~min}$ and reached a plateau between 60 and $120 \mathrm{~min}$ (Fig. 2). This plateau was not due to substrate exhaustion since $0.5-0.8 \mu \mathrm{M}$ araC was still present after 1-2 $\mathrm{h}$ incubation (see below). Blast cells from $\mathrm{T}$ lymphoblastic lymphoma showed the greatest araCTP formation of any leukemia, followed by myeloblasts, while lymphoblasts showed the least nucleoside triphosphate formation.

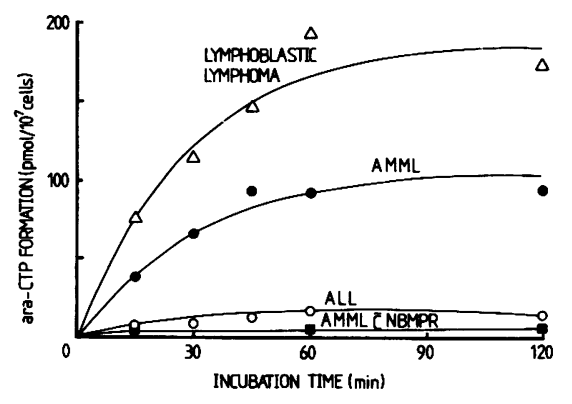

Figure 2. Time course of araCTP accumulation in three different acute leukemic blast cell suspensions. ${ }^{3} \mathrm{H}$-araC was added at a final concentration of $1.0 \mu \mathrm{M}$ to the cell suspension and samples taken at 15-120 min for assay of araCTP. Blast cells from a patient with AMML were also incubated in the presence of $3 \mu \mathrm{M}$ NBMPR to inhibit nucleoside transport.
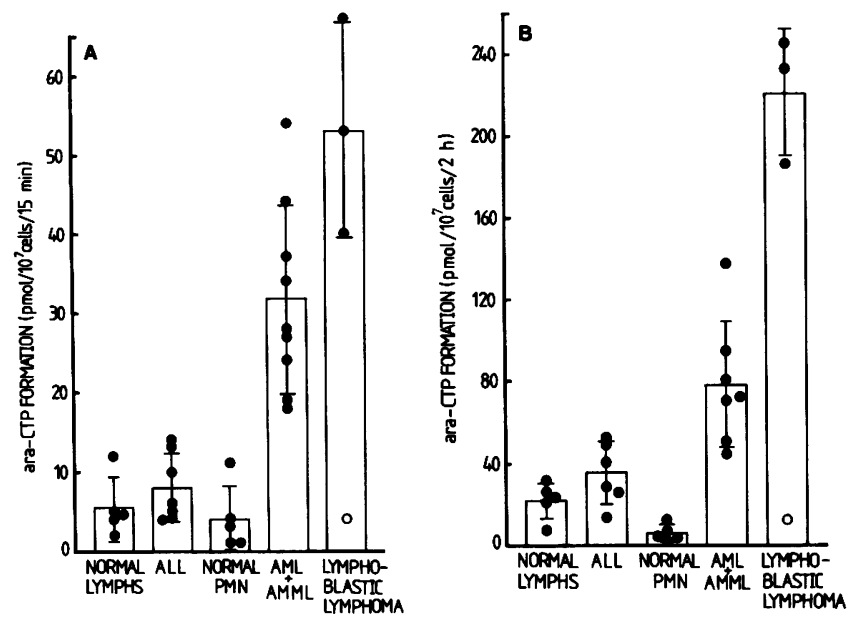

Figure 3. Accumulation of araCTP by blast cells incubated with 1 $\mu \mathrm{M}$ araC for either $(A) 15 \mathrm{~min}$ or $(B) 120 \mathrm{~min}$. Values for normal lymphocytes and normal polymorphs are included for comparison. A single patient with B cell lymphoma in leukemic phase (open circle) is shown but not included in the mean for $T$ cell lymphoblastic lymphoma. The patients with ALL were non-B and non-T type. Mean values \pm 1 SD are shown on the histogram.

In all leukemias studied, the addition of a nucleoside transport inhibitor, nitrobenzylthioinosine, reduced araCTP production to almost zero (mean value of $1.4 \%$ of uninhibited values).

AraCTP formation was measured in leukemic blast cells from 20 patients (nine AML and AMML, seven ALL, $3 \mathrm{~T}$ cell lymphoblastic lymphoma) as well as in normal lymphocyte and polymorph preparations. Fig. 3 shows that the mean araCTP formation from myeloblasts $\left(78.4 \mathrm{pmol} / 10^{7}\right.$ cells $\left./ 2 \mathrm{~h}\right)$ was significantly greater than the mean for lymphoblasts ( 35.3 pmol $/ 10^{7}$ cells $/ 2$ h; $\left.P<0.005\right)$. However, the highest araCTP formation was in blast cells from $\mathrm{T}$ lymphoblastic lymphoma (mean $221 \mathrm{pmol} / 10^{7}$ cells $/ 2 \mathrm{~h}$ ), which contrasted with the very low araCTP formed in blast cells of a rapidly advancing $B$ cell lymphoma in leukemic phase (12 pmol/10 cells $/ 2 \mathrm{~h})$. The same rank order of araCTP formation in different leukemias, i.e., $\mathrm{T}$ lymphoblastic lymphoma greater than myeloblasts greater than lymphoblasts, was observed after $15 \mathrm{~min}$ incubation with araC (Fig. $3 A$ ) as well as after $2 \mathrm{~h}$ (Fig. $3 \mathrm{~B}$ ). A striking difference was observed between the low araCTP formation in mature polymorphs and the high values observed in myeloblasts, although both cells are in the same maturation series $(P<0.001)$. In contrast, normal peripheral blood lymphocytes formed almost as much araCTP as their progenitor lymphoblasts (Fig. 3).

Metabolic products of araC. In all leukemias studied, araCTP was the major intracellular metabolite formed from ${ }^{3} \mathrm{H}$-araC. AraCTP accounted for $70-86 \%$ of the total acidsoluble radioactivity in the cells, while araCDP was only 8$10 \%$ (Table I). AraCMP could not be exactly quantitated because it co-migrated with araUMP on the thin layer chromatograms, but the sum of both was $<7 \%$. Very little free nucleoside was found intracellularly, since araC and araU, which separate together at the solvent front, accounted for $<6 \%$ of intracellular radioactivity (Table I). AraUTP was not a significant metabolite of $\mathrm{araC}$ as has been reported previously (11).

Significant formation of araU was observed in all leukemias, with ${ }^{3} \mathrm{H}$-araU appearing in the medium to reach concentrations 
Table I. Relative Proportion of Acid-soluble Metabolites of AraC

\begin{tabular}{llllll}
\hline Leukemic cell type & & araCTP & araCDP & araCMP + araUMP & Material at solvent front \\
\hline & $n$ & $\%$ & $\%$ & $\%$ & $\%$ \\
AML + AMML & 7 & $83.2 \pm 2.8$ & $8.0 \pm 2.5$ & $5.1 \pm 1.8$ & $3.6 \pm 1.7$ \\
Promyelocytic & 1 & 80.2 & 9.1 & 6.0 & 4.7 \\
ALL & 6 & $77.7 \pm 6.8$ & $9.2 \pm 4.2$ & $6.8 \pm 1.8$ & $6.3 \pm 3.9$ \\
Lymphoblastic lymphoma & & & & \\
$\quad$ T cell & 3 & $85.6 \pm 2.6$ & $7.8 \pm 0.6$ & $5.2 \pm 2.5$ & $1.4 \pm 0.4$ \\
B cell & 1 & 70.4 & 10.5 & 7.0 & 12.1
\end{tabular}

Leukemic blast cells were incubated for $15 \mathrm{~min}$ with $1 \mu \mathrm{M}$ araC and acid-soluble metabolites separated by thin-layer chromatography on PE1cellulose with $0.5 \mathrm{M}\left(\mathrm{NH}_{4}\right)_{2} \mathrm{SO}_{4}$ as solvent.

of $0.07-0.31 \mu \mathrm{M}$ after 120 min incubation with $1 \mu \mathrm{M}$ araC (Fig. 4). The accumulation of araU was significantly less in ALL than in AML $(P<0.005)$, and corresponded to a significantly lower utilization of araC in the ALL cells ( $P$ $<0.01$ ). However, even after $2 \mathrm{~h}$ incubation, extracellular ${ }^{3} \mathrm{H}$ $\operatorname{araC}$ was still present at levels of $0.5-0.8 \mu \mathrm{M}$.

Mean cell volume in different leukemias. Cell size was examined as a possible factor determining the amount of araCTP formed. In each experiment, the intracellular water space of blast cells or leucocytes was measured by a tritiated water technique $(27,28)$. Myeloblasts were $58-70 \%$ larger than lymphoblasts or mature polymorphs $(P<0.01$; Table II $)$, but there were no significant size differences between lymphoblasts, $T$ lymphoblastic lymphoma blasts, and mature lymphocytes. In some experiments, the protein content of blast cell extracts was also measured as an index of cell size. Myeloblasts contained a mean of $185 \pm 37 \mu \mathrm{g}$ protein $/ 10^{7}$ cells $(n=6)$ in contrast to lymphoblasts with $134 \pm 33 \mu \mathrm{g}$ protein $/ 10^{7}$ cells $(n$ $=5)$, and this difference of $35 \%$ was significant $(P=0.02)$. Thus, the mean size of myeloblasts is $35-70 \%$ larger than lymphoblasts, depending on the basis for comparison, but this

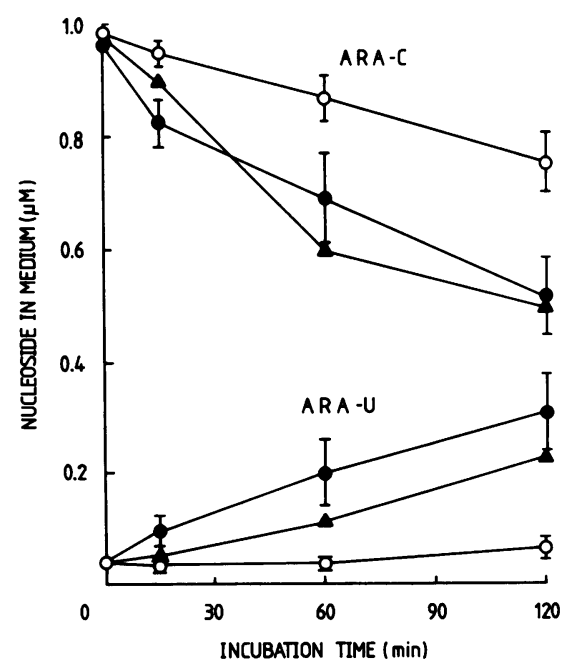

Figure 4. Conversion of araC to araU by leukemic blast cells. AraC was added at an initial concentration of $1 \mu \mathrm{M}$ to a cell suspension $\left(0.8-1.0 \times 10^{7} / \mathrm{ml}\right)$. At various incubation times the nucleosides present in the medium were analyzed by column chromatography. Values are the mean \pm 1 SEM. $\triangle$, T lymphoblastic lymphoma $(n=2)$; •, AML $(n=6)$; and 0 , ALL $(n=6)$. size difference cannot fully explain the two- to threefold difference in araCTP formation between the two leukemias. Moreover, T cell lymphoblastic lymphoma blasts were the same size as ALL (null or common) lymphoblasts although the $T$ cell variety accumulated sixfold more araCTP.

Deoxycytidine kinase activity. To seek an explanation for the wide variation in araCTP formation, the kinetic parameters of various enzymes metabolizing araC were assayed in lysates of blast cells from patients with different acute leukemias. The maximal velocity of deoxycytidine kinase was measured either with araC or deoxycytidine as substrate, and $V_{\max }$ varied over a sevenfold range between the different patients with AML and ALL, although the means for lymphoblasts and myeloblasts were not significantly different (Table III). The same conclusion held whether enzyme activity was expressed per milligram of cellular protein or per $10^{7}$ cells. Deoxycytidine kinase kinetics were studied in only two patients with $\mathrm{T}$ lymphoblastic lymphoma, but in both the $V_{\max }$ of this enzyme was less than the values in all other acute leukemias, while our data above demonstrates that lymphoblastic lymphoma forms the highest amount of araCTP (Table III). A consistent finding in all leukemias was that this enzyme displayed a higher $V_{\max }$ for araC than for deoxycytidine by a factor of 2.5-4-fold. Thus, variations in the amount of deoxycytidine kinase cannot account for the different araCTP accumulation in various leukemias.

Nucleoside monophosphate kinase activity. The kinetics of nucleoside monophosphate kinase were assayed on cell extracts with either ICMP or araCMP as substrate. In every leukemia the maximal velocities for this kinase were many orders of magnitude greater than for deoxycytidine kinase. There was a wide variation (up to eightfold) in the $V_{\max }$ between different patients which did not relate to the type of acute leukemia (Table IV). In all cases the $V_{\max }$ for araCMP as substrate was 2-4-fold greater than for dCMP as substrate. No correlation existed between the intracellular araCTP accumulation from $1 \mu \mathrm{M}$ araC after a 2-h incubation and the $V_{\max }$ of nucleoside monophosphate kinase $(r=0.39, P>0.2)$.

Deoxycytidylate deaminase activity. In the presence of 40 $\mu \mathrm{M}$ dCTP, the initial rate of conversion of dCMP to dUMP at various concentrations of dCMP was well described by Michaelis Menten kinetics (Fig. 5, $A$ and $B$ ). Full kinetic analyses were performed on cell extracts obtained from 37 patients with different leukemias and lymphomas, and Fig. 6 shows a comparison of the $V_{\max }$ values. Although the mean for myeloblasts $\left(939 \pm 459 \mathrm{pmol} / \mathrm{min} / 10^{6}\right.$ cells) was higher than 
Table II. Enumeration of Cell Size for Different Leukemic Blasts and Normal Cells

\begin{tabular}{lcllll}
\hline & & Total pellet water space & Trapped extracellular space & Intracellular water space & $\begin{array}{c}\text { Calculated mean } \\
\text { cell volume (fluid) }\end{array}$ \\
\hline & $n$ & $\mu l / 10^{7}$ cells & $\mu l / 10^{7}$ cells & $\mu l / 10^{7}$ cells & $f$ \\
ALL & 14 & $1.91 \pm 0.41$ & $0.23 \pm 0.08$ & $1.68 \pm 0.37$ & 202 \\
AML, AMML & 17 & $3.25 \pm 0.58$ & $0.32 \pm 0.11$ & $2.93 \pm 0.50$ & 353 \\
T Lymphoblastic lymphoma & 3 & $1.76 \pm 0.34$ & $0.25 \pm 0.01$ & $1.51 \pm 0.34$ & 182 \\
Normal lymphocytes & 5 & $1.70 \pm 0.08$ & $0.22 \pm 0.12$ & $1.47 \pm 0.19$ & 176 \\
Normal polymorphs & 4 & $2.21 \pm 0.46$ & $0.36 \pm 0.06$ & $1.86 \pm 0.41$ & 223 \\
\hline
\end{tabular}

Cells were suspended in imidazole-buffered saline, incubated for $5 \mathrm{~min}$ with either $\left[{ }^{3} \mathrm{H}\right] \mathrm{H}_{2} \mathrm{O}$ or ${ }^{14} \mathrm{C}$-polyethyleneglycol and the cells separated by centrifugation through phthalate oils. The difference between total and extracellular fluid space is taken as intracellular water space. The mean cell volumes was calculated from the intracellular water space, assuming cell water of $780 \mathrm{mg}$ water/g cells and a mean cell density of $1.065 \mathrm{pg} /$ fl. Mean values \pm 1 SD are shown.

lymphoblasts $\left(825 \pm 498 \mathrm{pmol} / \mathrm{min} / 10^{6}\right.$ cells $)$, there was considerable variability within each group, and the difference in means was not significant $(P=0.26)$. T lymphoblastic lymphoma gave values which were within the range found for ALL patients (Fig. 6). There were also no significant differences in the $K_{\mathrm{m}}$ value between lymphoblasts $(61 \pm 18 \mu \mathrm{M})$, myeloblasts $(61 \pm 20 \mu \mathrm{M})$, and $\mathrm{T}$ lymphoblastic lymphomas $(55 \pm 22 \mu \mathrm{M})$. Fig. 7 shows there was no correlation between the $V_{\max }$ of deoxycytidylate deaminase and the accumulation of araCTP after $2 \mathrm{~h}$ incubation of various leukemic cells with $1 \mu \mathrm{M}$ araC.

Nucleoside transport site density and its correlation with araCTP accumulation. Our previous work has shown that araC transport rate correlates with the number of transport sites measured by specific binding of ${ }^{3} \mathrm{H}-\mathrm{NBMPR}$ to different leukemic cells (14). In the present study, myeloblasts showed a maximal ${ }^{3} \mathrm{H}-\mathrm{NBMPR}$ binding site density of $10,000 \pm 4,100$ sites/cell $(n=9)$, which was significantly higher than the value for lymphoblasts $(2,300 \pm 1,100$ sites/cell $n=7 ; P<0.001)$. The highest value for specific ${ }^{3} \mathrm{H}-\mathrm{NBMPR}$ binding site density was found in $\mathrm{T}$ cell lymphoblastic lymphoma, with values for three separate patients of $30,000,26,000$, and 26,000 sites/cell (mean 27,500 $\pm 2,600$ ). The affinity of NBMPR binding was calculated from the slope of the Scatchard plots and was similar in the three types of blast cell studied $\left(K_{d}\right.$ range $0.2-$
$1.0 \mathrm{nM})$. Fig. $\because(A$ and $B)$ shows that a close correlation existed between the maximal number of ${ }^{3} \mathrm{H}$-NBMPR binding sites per cell and the level of araCTP accumulation from 1 $\mu \mathrm{M}$ extracellular araC either at $15 \mathrm{~min}$ or at $2 \mathrm{~h}$ incubation $(r$ $=0.86, P<0.005$; and $r=0.94, P<0.005$, respectively). This correlation suggests that membrane transport is one major rate-limiting step for araCTP accumulation from araC at low extracellular concentrations $(1 \mu \mathrm{M})$ of this nucleoside.

\section{Discussion}

The conversion of araC to araCTP has been demonstrated in many cell types possessing the pathway shown in Fig. 1, which is normally utilized to 'salvage' the pyrimidine nucleoside deoxycytidine. The various factors which may influence the level of araCTP attained include transport (step 1), phosphorylation (steps 2, 3, and 4), and deamination (steps 5 and 6). At low concentrations of exogenous nucleoside, membrane transport appears to be a major rate-limiting step for nucleotide formation (32). Deoxycytidine kinase (step 2) may also have a pivotal role in araCTP formation, both through variations in the total enzyme activity in cells and also through feedback inhibition by dCTP on kinase-mediated phosphorylation of $\operatorname{araC}(33)$. Deamination of $\operatorname{araC}$ to araU (step 6) or of araCMP

Table III. Kinetic Parameters of Deoxycytidine Kinase in Acute Leukemia

\begin{tabular}{|c|c|c|c|c|c|}
\hline & & \multicolumn{2}{|c|}{$V_{\max }(\mathrm{pmol} / \mathrm{mg} \mathrm{protein} / \mathrm{min})$} & \multicolumn{2}{|l|}{$K_{\mathrm{m}}(\mu M)$} \\
\hline & & CdR & $\operatorname{araC}$ & CdR & araC \\
\hline \multirow[t]{4}{*}{ Lymphoblasts } & & 281 & 943 & 1.8 & 14.5 \\
\hline & & 734 & 2,397 & 6.5 & 28.8 \\
\hline & & 340 & 1,369 & 3.0 & 29.6 \\
\hline & Mean \pm SEM & $452 \pm 142$ & $1,570 \pm 432$ & $3.8 \pm 1.4$ & $24.3 \pm 4.9$ \\
\hline \multirow[t]{5}{*}{ Myeloblasts } & & 175 & 475 & 3.9 & 13.5 \\
\hline & & 533 & 1,558 & 9.9 & 26.3 \\
\hline & & 194 & 486 & 3.6 & 14.6 \\
\hline & & 101 & 444 & 3.7 & 15.7 \\
\hline & Mean \pm SEM & $251 \pm 96$ & $741 \pm 273$ & $5.3 \pm 1.5$ & $17.5 \pm 3.0$ \\
\hline T Lymphoblastic & & 87 & 318 & 1.1 & 19.5 \\
\hline lymphoma blasts & & 75 & 456 & 0.8 & 9.9 \\
\hline
\end{tabular}


Table IV. Kinetic Parameters for Pyrimidine Nucleoside Monophosphate Kinase in Acute Leukemia

\begin{tabular}{|c|c|c|c|c|c|}
\hline & & \multicolumn{2}{|c|}{$V_{\max }(\mathrm{nmol} / \mathrm{mg}$ prolein $/ \mathrm{min})$} & \multicolumn{2}{|l|}{$K_{\mathrm{m}}(m M)$} \\
\hline & & dCMP & araCMP & dCMP & araCMP \\
\hline Lymphoblasts & & 78 & 247 & 2.1 & 1.2 \\
\hline \multirow[t]{5}{*}{ Myeloblasts } & & 56 & 105 & 2.7 & 0.6 \\
\hline & & 126 & 238 & 1.8 & 0.7 \\
\hline & & 15 & 49 & 1.9 & 1.0 \\
\hline & & 45 & 100 & 1.9 & 0.5 \\
\hline & Mean \pm SEM & $61 \pm 23$ & $123 \pm 40$ & $2.1 \pm 0.2$ & $0.7 \pm 0.1$ \\
\hline T Lymphoblastic & & 63 & 304 & 3.2 & 1.4 \\
\hline lymphoma blasts & & 67 & 226 & 2.1 & 0.8 \\
\hline
\end{tabular}

to araUMP (step 5) may also limit the accumulation of araCTP, particularly since deoxycytidylate deaminase is known to have high activity in leukemic tissue $(34,35)$. The kinetic behavior of this latter enzyme is complex, with dCTP acting as an allosteric activator of deamination (26). Finally, pyrimidine nucleoside monophosphate kinase (step 3) and nucleoside diphosphate kinase (step 4) have higher activity than deoxycytidine kinase (step 2) in extracts of fresh leukemic blasts, and are unlikely to be rate limiting (24).

Hamster fibroblasts (Nil 8), metastatic melanoma cells, murine L1210 leukemic cells, and human leukemic myeloblasts can all form araCTP, although the various published studies used different araC concentrations and incubation times, which make quantitative comparisons difficult (10-12, 32, 36-38).
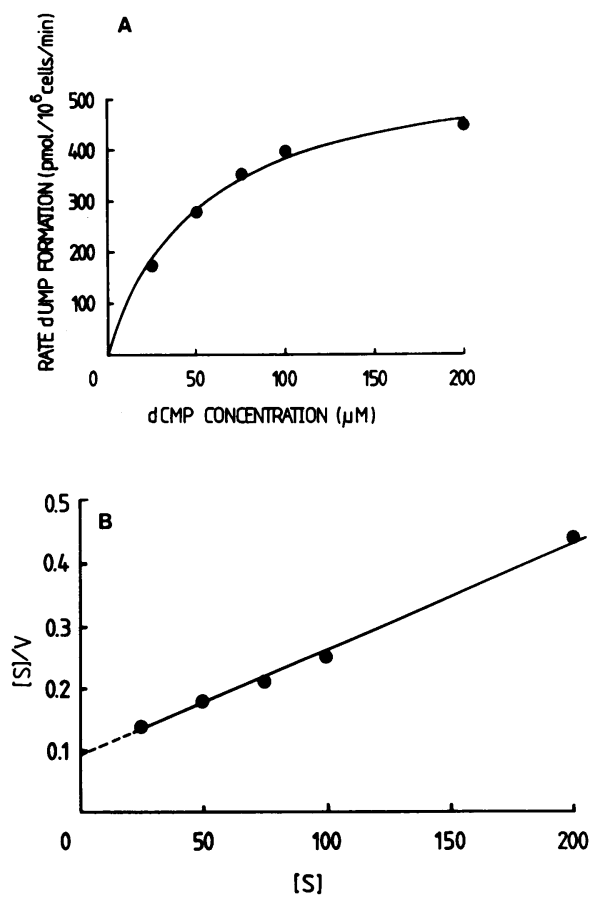

Figure 5. $(A)$ Dependence of deoxycytidylate deaminase activity on substrate concentration. An extract of lymphoblasts was incubated for 1-4 min with 25-200 $\mu \mathrm{M}$ dCMP in the presence of $40 \mu \mathrm{M}$ dCTP. The curve was fitted by a nonlinear regression analysis program. (B) A kinetic plot of S/V vs. S for deoxycytidylate deaminase activity. Regression line was fitted by the method of least squares.
Except for one study (12), there is agreement that myeloblasts invariably accumulate some araCTP, and studies have generally focussed on the critical concentration of araCTP necessary for a clinical response to $\operatorname{araC}(10,11)$. Fig. 2 shows the rapid rise in araCTP during $45 \mathrm{~min}$ incubation, with the nucleoside triphosphate reaching a plateau value between 60 and 120 min as reported previously (10). There is a wide variability in the amount of araCTP formed in myeloblasts of different patients, although the mean value in this study $\left(78 \mathrm{pmol} / 10^{7}\right.$ cells/2 h; $n=7$ ) shows good concordance with that obtained by Harris and Grahame-Smith (10) $\left(72 \mathrm{pmol} / 10^{7}\right.$ cells $/ 45 \mathrm{~min}$; $n=25$ ) in a study which also incubated blasts with $1 \mu \mathrm{M}$ araC. Similar values of araCTP have been observed in leukemic blast cells removed from patients receiving continuous intravenous infusions of araC at a dosage of $50 \mathrm{mg} / \mathrm{m}^{2} / \mathrm{d}$ (39). In this study, the major nucleotide product of araC metabolism by fresh leukemic blast cells was always araCTP, which accounted for $70-86 \%$ of the acid-soluble metabolites (Table I). Little araCDP $(<10 \%)$ or araCMP plus araUMP $(<7 \%)$ accumulated, and these nucleotides remained in constant proportion between $15 \mathrm{~min}$ and $2 \mathrm{~h}$ incubation. In agreement with a previous report (11), we found no detectable formation of araUTP. AraCDP-choline and araCDP-ethanolamine are both major metabolites of araC added to cultured RPMI 6410 cells (21). These compounds were not resolved from free intracellular nucleosides (araC plus araU), but all four together accounted for $<6.3 \%$ of the intracellular metabolites, except in cells

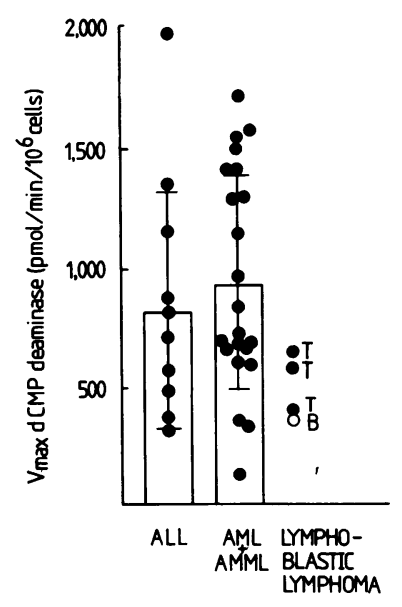

Figure 6. Maximum velocity of deoxycytidylate deaminase in extracts of blasts from patients with various leukemias. AML blasts and $A M M L$ blasts were analyzed together while values for three patients with $\mathrm{T}$ lymphoblastic lymphoma and a single patient with B lymphoma in leukemic phase are shown. Mean values \pm 1 SD are shown on the histogram. 


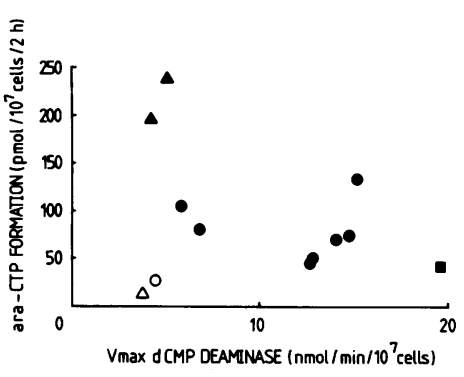

from the single B cell lymphoma patient where the total reached $12.1 \%$.

Large variation in the accumulation of araCTP was observed between the different leukemias and followed the rank order T lymphoblastic lymphoma greater than myeloblasts greater than lymphoblasts. A previous study has also shown that myeloblasts have a greater capacity than lymphoblasts to convert araC to araCTP (11). Enzymatic factors, which may contribute to the observed difference, were assessed by measuring three enzymes involved in araC metabolism (steps 2, 3, and 5 of Fig. 1). First, any difference in the content of deoxycytidine kinase between myeloblasts and lymphoblasts was excluded by our assays of this enzyme (Table III). The
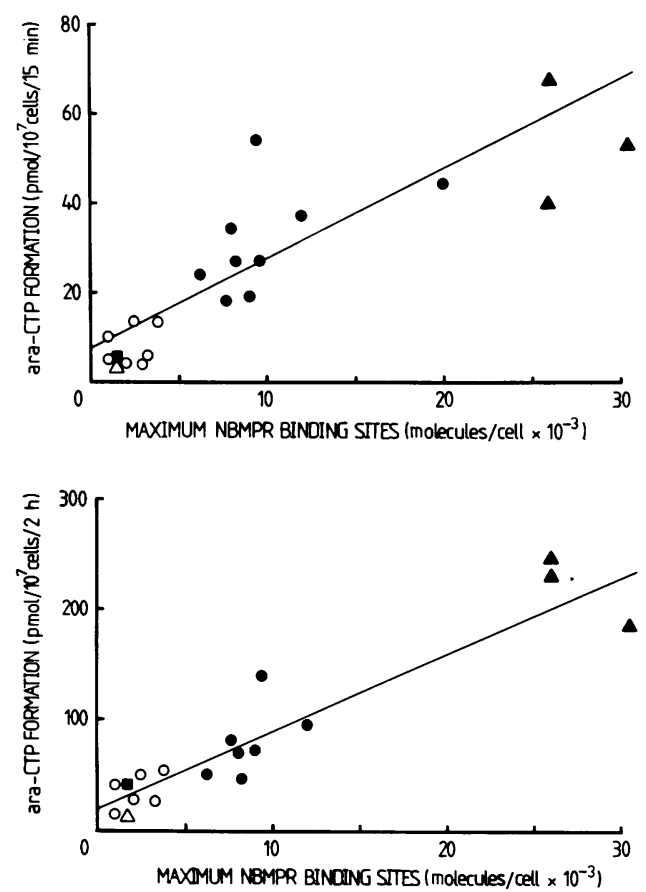

Figure 8. Correlation between accumulation of araCTP and nucleoside transport capacity measured by the maximum number of NBMPR binding sites on blasts. AraCTP formation was measured after incubation of blasts with $1 \mu \mathrm{M}{ }^{3} \mathrm{H}$-araC for $(A) 15 \mathrm{~min}$ and $(B)$ 120 min. $\Delta, T$ lymphoblastic lymphoma; $\triangle$, B cell lymphoma in leukemic phase; •, AML and AMML; O, ALL; a, acute promyelocytic leukemia. Regression line was fitted by the method of least squares and for $A, r=0.86, P<0.005$; and for $B, r=0.94, P$ $<0.005$. maximal velocity of this kinase, assayed on cell lysates, did not differ between myeloblasts and lymphoblasts, whether maximal velocity of the kinase was expressed per $10^{7}$ blast cells or per milligram cell protein. However, deoxycytidine kinase from all leukemic cell types always yielded higher $V_{\max }$ values for araC than for deoxycytidine, as has been reported previously $(22,40)$. The second enzyme to be assayed was pyrimidine nucleoside monophosphate kinase (step 3 of Fig. 1). The values for $V_{\max }$ and $K_{\mathrm{m}}$ of this enzyme shown in Table IV are similar to those reported previously in acute leukemic blasts (24) and in both studies there were no differences in $V_{\max }$ between myeloblasts and lymphoblasts. Either with the natural substrate (dCMP) or its analogue (araCMP), pyrimidine nucleoside monophosphate kinase showed a $V_{\max }$ that was several orders of magnitude greater than that for deoxycytidine kinase (compare tables III and IV). It is thus unlikely that the activity of this enzyme could be rate limiting for araCTP formation, and this conclusion is supported by the lack of correlation between araCTP and enzyme $V_{\max }$ values in the different leukemia.

A third enzyme of araC metabolism, deoxycytidylate deaminase, was assayed, since the deamination of araCMP may potentially limit the accumulation of araCTP (34). The kinetic behavior of the enzyme is complex, and the addition of dCTP changes the substrate dependence of reaction velocity from allosteric to Michaelian (26). In the present study, $40 \mu \mathrm{M}$ dCTP was always added to the assay mixtures and the kinetics were well described by a Mịchaelis-Menten analysis (see Fig. $5, A$ and $B$ ). The $V_{\max }$ for deoxycytidylate deaminase of myeloblasts was not significantly different from that of lymphoblasts (Fig. 6), and both were similar to values reported recently for lymphoblasts (41). Moreover three patients with T lymphoblastic lymphoma gave $V_{\max }$ values similar to lymphoblasts from non-T ALL as well as a single patient with B lymphoma in leukemic phase. Thus, variations in the amount of deoxycytidylate deaminase cannot explain the very high araCTP accumulation observed in $\mathrm{T}$ lymphoblastic lymphoma blasts. The lack of correlation between araCTP levels and $V_{\max }$ of deoxycytidylate deaminase measured in the same leukemic blasts (Fig. 7) does not support the concept that araCMP deamination is the major factor limiting araCTP accumulation from $1 \mu \mathrm{M}$ araC. Deamination of araC to araU by cytidine deaminase has been considered but generally rejected by others as a potential factor limiting conversion of araC to araCTP $(10,37,40)$. Our data in Fig. 4 shows little araU formation by intact lymphoblasts, so that excessive deamination of araC cannot explain the low araCTP accumulation by lymphoblasts. In two studies the rate of araC deamination in leukemic blast cells was found to be unrelated to the extent of araC phosphorylation measured either by araCTP formation (in intact cells) or deoxycytidine kinase assays (on broken cells) from different patients $(22,40,42)$. Thus, none of the assays of enzymes metabolizing araC provide a satisfactory explanation for the sixfold range in araCTP accumulation by different leukemic blasts.

In contrast, our data offers strong support for the concept that membrane tranșport of $\operatorname{araC}($ at $1 \mu \mathrm{M})$ is a major ratelimiting step in the conversion of nucleoside to its triphosphate. Fig. 8 shows a strong correlation exists between the maximum density of ${ }^{3} \mathrm{H}-\mathrm{NBMPR}$ binding sites and araCTP accumulation in fresh leukemic blasts of different types. We have previously 
shown that membrane transport of araC is directly proportional to the maximum density of ${ }^{3} \mathrm{H}$-NBMPR binding sites, and both are fourfold greater for myeloblasts than for lymphoblasts (14). Other studies have also linked the facilitated transport rate of nucleosides to the maximum number of NBMPR binding sites in a wide range of cultured cells (43-45). The importance of membrane transport in limiting araCTP formation is also suggested by the low araC influx into blasts of some patients with acute leukemia who fail to respond to chemotherapy containing araC (14).

The number of nucleoside transport sites increases with the size and surface area of a cell. Thus myeloblasts which are on average $35-70 \%$ larger than lymphoblasts might be expected to have more transport sites and larger araCTP formation. However, this size factor cannot explain the entire difference or account for the very large araCTP formation in T lymphoblastic lymphoma. Indeed these $T$ cells accumulate sixfold more araCTP than non-T lymphoblasts from patients with ALL, although lymphoid blasts of all types were the same size (Table II). Another major factor which influences the density of nucleoside transport sites is the proportion of cells in the proliferative cycle. Cultured human cells growing exponentially have a growth fraction close to 1.0 , and densities of nucleoside transporters between 60,000 and 330,000 sites per cell. In contrast, mature nondividing polymorphs and lymphacytes have extremely low densities of nucleoside transporters of 1,000-2,500 sites/cell (14). Other studies show the ${ }^{3} \mathrm{H}-\mathrm{NBMPR}$ binding site density as well as the conversion of araC to araCTP vary up to twofold with the phase of the cell cycle, being greater in late $G_{1}$ and S-phase $(46,47)$. These observations suggest that cytokinetic properties can explain much of the difference between various leukemic blasts. In another study, $T$ lymphoblasts from peripheral blood showed a higher labeling index than "common" lymphoblasts (48) so that a greater proliferative activity is likely to contribute to the high density of nucleoside transporters (27,500 sites/cell) found in T lymphoblastic lymphoma blasts. Whether some intrinsic biochemical characteristic also contributes to the different density of ${ }^{3} \mathrm{H}-\mathrm{NBMPR}$ binding sites in various leukemias remains to be defined.

An important finding in the present study was that blast cells from $\mathrm{T}$ lymphoblastic lymphoma showed both the greatest nucleoside transport capacity and the highest conversion of araC to araCTP of any fresh human leukemia or lymphoma studied. The comparison of $\mathrm{T}$ lymphoma with $\mathrm{B}$ lymphoma in leukemic phase was particularly striking, since $T$ cells transported nucleoside and formed araCTP some 15-fold more than B cells (Figs. 3 and 8 ). The ability of $\mathrm{T}$ lymphoblasts to accumulate very high levels of ribo- or deoxyribonucleotides from exogenous nucleosides is well documented. Freshly isolated leukemic $\mathrm{T}$ lymphoblasts convert more deoxyadenosine to deoxyATP than do the usual null-lymphoblasts $(49,50)$. Cultured leukemic $T$ lymphoblasts incubated with growth inhibitory concentrations of thymidine, deoxyguanosine, or deoxyadenosine form large amounts of the respective deoxynucleoside triphosphates, while under similar conditions B cell lines show little change in their intracellular pools of deoxynucleotides (51). Investigators have been puzzled for many years by the extreme sensitivity of $T$ cell lymphoblasts to the cytotoxic action of araC (52). Indeed, cultured T lymphoblasts of the MOLT-4 type formed 10-fold more araCTP from a low concentration of $\operatorname{araC}(0.1 \mu \mathrm{M})$ than non-T lymphoblasts of the Raji or Daudi cell lines (53). However, the biochemical basis by which $\mathrm{T}$ lymphoblasts accumulate such large amounts of nucleotides from exogenous nucleosides was unclear. Variations in nucleoside kinase activity must be considered, but the present study shows the same amount of deoxycytidine kinase in T lymphoblasts, non- $\mathrm{T}$ lymphoblasts, and myeloblasts from peripheral blood. Variable rates of nucleoside triphosphate degradation has been suggested to control the accumulation of these compounds $(12,51,53)$. However, our study suggests that membrane transport of nucleosides may be an even more important rate-limiting step for nucleoside triphosphate accumulation when cells are exposed to low concentrations $(1 \mu \mathrm{M})$ of nucleosides.

These studies have important implications for the treatment of $\mathrm{T}$ lymphoblastic lymphoma with cytotoxic nucleosides. Little data using araC is available, since this drug is not generally included in the initial therapy of either ALL or any of the lymphomas. However, historical studies show that araC used as a single agent produced complete response rates of 3$32 \%$ in childhood ALL $(1,2)$. Since these studies predated the recognition of $\mathrm{T}$ lymphoblastic lymphoma as a distinct clinicalpathological entity, it is tempting to suggest that the responders had a leukemic phase of this $T$ cell disease which is often morphologically indistinguishable from ALL. We have treated one patient with bone marrow relapse of $\mathrm{T}$ lymphoblastic lymphoma with $\operatorname{araC}\left(100 \mathrm{mg} / \mathrm{m}^{2} / \mathrm{d}\right.$ i.v. $\left.\times 7 \mathrm{~d}\right)$ and produced complete remission with two cycles of this single agent chemotherapy (Wiley, J. S., and R. K. Woodruff, unpublished observations). Further clinical trials of araC in the therapy of T lymphoblastic lymphoma are needed to confirm our biochemical prediction that araC is active in this disease.

\section{Acknowledgments}

We thank A. R. P. Paterson for helpful suggestions and gifts of NBMPR and Dr. Roger Woodruff for stimulating discussions. We are grateful for the generous cooperation of many physicians including Drs. G. Brodie, I. Cooper, J. Ding, J. Duggan, H. Ekert, B. Firkin, F. Firkin, R. Harris, N. Lee, J. D. Parkin, D. Penington, B. Rush, P. Thurlow, K. Tiedemann, M. van der Weyden, K. Waters, M. Whiteside, M. Wilson, M. Wolf, and R. Woodruff.

This work was supported by a grant from the Anti-Cancer Council of Victoria.

\section{References}

1. Howard, J. P., V. Albo, and W. A. Newton. 1968. Cytosine arabinoside. Results of a cooperative study in acute childhood leukemia. Cancer (Phila.). 21:341-345.

2. Wang, J. J., O. S. Selawry, T. J. Vietti, and G. P. Bodey. 1970. Prolonged infusion of arabinosyl cytosine in childhood leukemia. Cancer (Phila.). 25:1-6.

3. Traggis, D. G., A. Dohluitz, L. Das, N. Jaffe, W. C. Moloney, and T. C. Hall. 1971. Cytosine arabinoside in acute leukemia of childhood. Cancer (Phila.). 28:815-818.

4. Bryan, J. H., E. S. Henderson, and B. G. Leventhal. 1974. Cytosine arabinoside and 6-thioguanine in refractory lymphocytic leukemia. Cancer (Phila.). 33:539-544.

5. Rivera, G., R. J. Aur, G. V. Dahl, C. B. Pratt, A. Wood, and 
T. L. Avery. 1980. Combined VM-26 and cytosine arabinoside in treatment of refractory childhood lymphocytic leukemia. Cancer (Phila.). 45:1284-1288.

6. Gingrich, R. D., J. O. Armitage, and C. P. Burns. 1978. Treatment of adult acute lymphoblastic leukemia with cytosine arabinoside, vincristine and prednisone. Cancer Treat. Rep. 62:1389-1391.

7. Momparler, R. 1972. Kinetic and template studies with 1- $\beta$-Darabinofuranosylcytosine 5 -triphosphate and mammalian deoxyribonucleic acid polymerase. Mol. Pharmacol. 8:362-370.

8. Major, P. P., E. M. Egan, G. P. Beardsley, M. D. Minden, and D. W. Kufe. 1981. Lethality of human myeloblasts correlates with the incorporation of arabinofuranosylcytosine into DNA. Proc. Natl. Acad. Sci. USA. 78:3235-3239.

9. Kufe, D., D. Spriggs, E. M. Egan, and D. Munroe. 1984. Relationships among ara-CTP pools, formation of (araC)DNA, and cytotoxicity of human leukemic cells. Blood. 64:54-58.

10. Harris, A. L., and D. G. Grahame-Smith. 1982. The relationship of ara-C metabolism in vitro to therapeutic response in acute myeloid leukemia. Cancer Chemother. Pharmacol. 9:30-35.

11. Chou, T. C., Z. Arlin, B. D. Clarkson, and F. S. Phillips. 1977. Metabolism of 1- $\beta$-D-arabinofuranosyl cytosine in human leukemic cells. Cancer Res. 37:3561-3570.

12. Rustum, Y. M., and H. D. Preisler. 1979. Correlation between leukemic cell retention of $1-\beta$-D-arabinofuranosylcytosine-5-triphosphate and response to therapy. Cancer Res. 39:42-49.

13. Rustum, Y. M., and H. D. Preisler. 1981. Factors that may determine cellular selectivity: role of ribonucleotide pools and de novo versus salvage pathways. In Nucleosides and Cancer Treatment. M. H. N. Tattersall and Y. M. Rustum, editors. Academic Press, Sydney. 46-56.

14. Wiley, J. S., S. P. Jones, W. H. Sawyer, and A. R. P. Paterson. 1982. Cytosine arabinoside influx and nucleoside transport sites in acute leukemia. J. Clin. Invest. 69:479-489.

15. Wiley, J. S., S. P. Jones, and W. H. Sawyer. 1983. Cytosine arabinoside transport by human leukemic cells. Eur. J. Cancer Clin. Oncol. 18:1067-1074.

16. Tattersall, M. H. N., K. Ganeshaguru, and A. V. Hoffbrand. 1974. Mechanisms of resistance of human acute leukemia cells to cytosine arabinoside. Br. J. Haematol. 27:39-46.

17. Bagnara, A. S., and L. R. Finch. 1972. Quantitative extraction and estimation of intracellular nucleoside triphosphates of Escherischia coli. Anal. Biochem. 45:24-34.

18. Madsen, N. P. 1969. Use of toluene/triton X100 scintillation mixture for counting ${ }^{14} \mathrm{C}$-protein radioactivity. Anal. Biochem. 29:542544.

19. Bennett, J. M., D. Catovsky, M. T. Daniel, G. Flandrin, D. A. G. Galton, H. R. Gralnick, and C. Sultan. 1976. Proposals for the classification of the acute leukemias. French-American-British (FAB) co-operative group. Br. J. Haematol. 33:451-458.

20. Nathwani, B. N. 1979. A critical analysis of the classifications of non-Hodgkin's lymphomas. Cancer (Phila.). 44:347-384.

21. Lauzon, G. J., J. H. Paran, and A. R. P. Paterson. 1978. Formation of 1- $\beta$-D-arabinofuranosylcytosine diphosphate choline in cultured human leukemic cells. Cancer Res. 38:1723-1729.

22. Coleman, C. N., R. G. Stoller, J. C. Drake, and B. A. Chabner. 1975. Deoxycytidine kinase: properties of the enzyme from human leukemic granulocytes. Blood. 46:791-803.

23. Bradford, M. M. 1976. A rapid and sensitive method for the quantitation of microgram quantities of protein utilizing the principle of protein-dye binding. Anal. Biochem. 72:248-254.

24. Hande, K. R., and B. A. Chabner. 1978. Pyrimidine nucleoside monophosphate kinase from human leukemic blasts cells. Cancer Res. 38:579-585.

25. Neale, G. A. M., A. Mitchell, and L. R. Finch. 1983. Enzymes of pyrimidine deoxyribonucleotide metabolism in Mycoplasma mycoides subsp. mycoides. J. Bacteriol. 156:1001-1005.
26. Maley, F., and G. F. Maley. 1971. The regulatory influence of allosteric effectors on deoxycytidylate deaminases. Curr. Top. Cell. Regul. 5:177-228.

27. Bui, A. H., and J. S. Wiley. 1981. Cation fluxes and volume regulation by human lymphocytes. J. Cell. Physiol. 108:47-54.

28. Wiley, J. S., M. A. Quinn, and J. M. Connellan. 1983. Estimation of platelet size by measurement of intracellular water space using an oil technique. Thromb. Res. 31:261-268.

29. Klotz, I. M. 1982. Number of receptor sites from Scatchard graphs: facts and fantasies. Science (Wash. DC). 217:1247-1249.

30. Koeppe, P., and C. Hamann. 1980. A program for non-linear regression analysis to be used on desk top computers. Comput. Programs Biomed. 12:121-128.

31. Duggleby, R. G. 1981. A non-linear regression program for small computers. Anal. Biochem. 110:9-18.

32. Heichal, O., D. Ish-Shalom, R. Koren, and W. D. Stein. 1979. The kinetic dissection of transport from metabolic trapping during substrate uptake by intact cells. Uridine uptake by quiescent and serum activated Nil 8 hamster cells and their murine sarcoma virus-transformed counterparts. Biochim. Biophys. Acta. 551:169-186.

33. Harris, A. W., E. C. Reynolds, and L. R. Finch. 1979. Effects of thymidine on the sensitivity of cultured mouse tumor cells to $1-\beta$ D-arabinofuranosylcytosine. Cancer Res. 39:538-541.

34. Ellims, P. H., A. Y. Kao, and B. A. Chabner. 1983. Kinetic behavior and allosteric regulation of deoxycytidylate deaminase derived from leukemic cells. Mol. Cell. Biochem. 57:185-190.

35. Mancini, W. R., and Y. C. Cheng. 1983. Human deoxycytidylate deaminase: substrate specificity and their chemotherapeutic implications. Mol. Pharmacol. 23:159-164.

36. Hart, J. S., D. H. Ho, S. L. George, P. Salem, J. A. Gottlieb, and E. Frei III. 1972. Cytokinetic and molecular pharmacology studies of arabinosylcytosine in metastatic melanoma. Cancer Res. 32:27112716 .

37. Smyth, J. F., A. B. Robins, and C. L. Leese. 1976. The metabolism of cytosine arabinoside as a predictive test for clinical response to the drug in acute myeloid leukemia. Eur. J. Cancer 12:567-573.

38. Kessell, D., and S. B. Shurin. 1968. Transport of two nonmetabolised nucleosides, deoxycytidine and cytosine arabinoside, in a subline of the L1210 murine leukemia. Biochim. Biophys. Acta. 163:179-187.

39. Barlogie, B., W. Plunkett, M. Raber, J. Latreille, M. Keating, and K. McCredie. 1981. In vivo cellular kinetic and pharmacological studies of 1- $\beta$-D-arabinofuranosylcytosine and 3-deazauridine chemotherapy for relapsing acute leukemia. Cancer Res. 41:1227-1235.

40. Mejer, J., and P. Nygaard. 1978. Cytosine arabinoside phosphorylation and deamination in acute myeloblastic leukemic cells. Leuk. Res. 2:127-131.

41. Ellims, P. H., and G. M. Medley. 1984. Deoxycytidylate deaminase activity in lymphoproliferative disorders. Leuk. Res. 8:123128.

42. Harris, A. L., D. G. Grahame-Smith, C. G. Potter, and C. Bunch. 1981. Cytosine arabinoside deamination in human leukemic myeloblasts and resistance to cytosine arabinoside therapy. Clin. Sci. 60:191-198.

43. Cass, C. E., N. Kolassa, Y. Uehara, E. Dahlig-Harley, E. R. Harley, and A. R. P. Paterson. 1981. Absence of binding sites for the transport inhibitor nitrobenzylthioinosine on nucleoside transportdeficient mouse lymphoma cells. Biochim. Biophys. Acta. 649:769777.

44. Lauzon, G. H., and A. R. P. Paterson. 1977. Binding of the nucleoside transport inhibitor nitrobenzylthioinosine to HeLa cells. Mol. Pharmacol. 13:883-891.

45. Paterson, A. R. P., S. Yang, E. Y. Lau, and C. E. Cass. 1979. Low specificity of the nucleoside transport mechanism of RPMI 6410 cells. Mol. Pharmacol. 16:900-908. 
46. Vierwinden, G., A. M. Drenthe-Schonk, A. M. Plas, P. C. M. Linssen, A. H. M. Pennings, R. S. G. Holdrinet, J. van Egmond, J. M. C. Wessels, and C. A. M. Haanen. 1982. Variations of the phosphorylation of 1- $\beta$-D-arabinofuranosyl cytosine (ara-C) in human myeloid leukemic cells related to the cell cycle. Leuk. Res. 6:251-259.

47. Cass, C. E., E. Dahlig, E. Y. Lau, T. P. Lynch, and A. R. P. Paterson. 1979. Fluctuations in nucleoside uptake and binding of the inhibitor of nucleoside transport, nitrobenzylthioinosine, during the replication cycle of HeLa cells. Cancer Res. 39:1245-1252.

48. Dow, L. W., L. J. A. Chang, A. A. Tsiatis, S. L. Melvin, and W. P. Bowman. 1982. Relationship of pretreatment lymphoblast proliferative activity and prognosis in 97 children with acute lymphoblastic leukemia. Blood. 59:1197-1202.

49. Sylwestrowicz, T., A. Piga, P. Murphy, K. Ganeshaguru, N. H. Russell, H. G. Prentice, and A. V. Hoffbrand. 1982. The effects of deoxycoformycin and deoxyadenosine on deoxyribonucleotide concentrations in leukemic cells. Br. J. Haematol. 51:623-630.

50. Matsumoto, S. S., A. L. Yu, L. C. Bleeker, B. Bakay, F. H. Kung, and W. L. Nyhan. 1982. Biochemical correlates of the differential sensitivity of subtypes of human leukemia to deoxyadenosine and deoxycoformycin. Blood. 60:1096-1102.

51. Fox, R. M., S. K. Piddington, E. H. Tripp, and M. H. N. Tattersall. 1981. Ecto-adenosine triphosphatase deficiency in cultured human $\mathrm{T}$ and null leukemic lymphocytes. A biochemical basis for thymidine sensitivity. J. Clin. Invest. 68:544-552.

52. Ohnuma, T., H. Arkin, J. Minowada, and J. F. Holland. 1978 Differential chemotherapeutic sensitivity of human T-lymphocytes and B-lymphocytes in culture. J. Nat. Cancer Inst. 60:749-752.

53. Abe, I., S. Saito, K. Hori, M. Suzuki, and H. Sato. 1982. Role of dephosphorylation in accumulation of 1- $\beta$-D-arabinofuranosylcytosine 5'-triphosphate in human lymphoblastic cell lines with reference to their drug sensitivity. Cancer Res. 42:2846-2851. 